\title{
Tissue cholesterol content alterations in streptozotocin-induced diabetic rats
}

\author{
Xin-ting WANG, Jia LI, Li LIU, Nan HU, Shi JIN, Can LIU, Dan MEI, Xiao-dong LIU* \\ Key Laboratory of Drug Metabolism and Pharmacokinetics, China Pharmaceutical University, Nanjing 210009, China
}

\begin{abstract}
Aim: Diabetes is associated with elevated serum total cholesterol level and disrupted lipoprotein subfractions. The aim of this study was to examine alterations in the tissue cholesterol contents closely related to diabetic complications.

Methods: Intraperitoneal injection of streptozotocin was used to induce type 1 diabetes in adult male Sprague-Dawley rats. On d 35 after the injection, liver, heart, intestine, kidney, pancreas, cerebral cortex and hippocampus were isolated from the rats. The content of total and free cholesterol in the tissues was determined using HPLC. The ATP-binding cassette protein A1 (ABCA1) protein and ApoE mRNA were measured using Western blot and QT-PCR analyses, respectively.

Results: In diabetic rats, the level of free cholesterol was significantly decreased in the peripheral tissues, but significantly elevated in hippocampus, as compared with those in the control rats. Diabetic rats showed a trend of decreasing the total cholesterol level in the peripheral tissues, but significant change was only found in kidney and liver. In diabetic rats, the level of the ABCA1 protein was significantly increased in the peripheral tissues and cerebral cortex; the expression of ApoE mRNA was slightly decreased in hippocampus and cerebral cortex, but the change had no statistical significance.

Conclusion: Type 1 diabetes decreases the free cholesterol content in the peripheral tissues and increases the free cholesterol content in hippocampus. The decreased free cholesterol level in the peripheral tissues may be partly due to the increased expression of the ABCA1 protein.
\end{abstract}

Keywords: diabetes; cholesterol; ABCA1; liver X receptor; apolipoprotein E

Acta Pharmacologica Sinica (2012) 33: 909-917; doi: 10.1038/aps.2012.50; published online 18 Jun 2012

\section{Introduction}

The maintenance of cellular cholesterol homeostasis is important for normal physiological processes. Type 1 diabetes mellitus (T1DM) is associated with an imbalance of cholesterol homeostasis, which results in an increased risk of death in diabetic patients. It has been estimated that $51 \%$ of patients with type 1 diabetes mellitus in the US and Europe showed hypercholesterolemia ${ }^{[1]}$. The accumulation of esterified cholesterol in macrophages is an essential step in the progression of atherosclerotic lesions ${ }^{[2]}$. Animal experiments showed that an induction of hypercholesterolemia in mice triggered a rapid ingestion of lipid by resident intimal dendritic cells, which led to nascent foam cell lesion formation ${ }^{[3]}$ and exaggerated atherosclerosis ${ }^{[4]}$. Disordered cholesterol homeostasis induced by diabetes also affects other physiological processes. A report showed that the red blood cell membranes from diabetic patients became rigid due to changes in the cholesterol-

\footnotetext{
* To whom correspondence should be addressed.

E-mail xdliu@cpu.edu.cn

Received 2012-02-10 Accepted 2012-04-11
}

to-phospholipid ratio, which resulted in microangiopathic hemolytic anemia ${ }^{[5]}$. Accumulating epidemiological evidence shows that there is a clear link between cholesterol levels and neurodegenerative diseases including Alzheimer's disease (AD) and Parkinson's disease ${ }^{[6,7]}$.

Type 1 diabetes mellitus is a chronic metabolic syndrome characterized by complications including macrovascular and microvascular diseases. Alterations of cholesterol levels in tissues may be a factor contributing to the diabetic complications. However, previous cholesterol disorder studies focused on the serum or macrophages, and information on tissues under diabetic states has not been fully examined. An important way to maintain cellular cholesterol homeostasis is reverse cholesterol transport (RCT) via cholesterol transporters ${ }^{[8]}$. ATP-binding cassette protein A1 (ABCA1) is an important rate-controlling protein in reverse cholesterol transport. Several reports showed that the expression of the ABCA1 protein was altered under diabetic states ${ }^{[9,10]}$.

The aim of this study was to investigate the cholesterol content in tissues related to cholesterol metabolism and diabetic complications using streptozotocin (STZ)-induced diabetic 
rats. The expression of the $\mathrm{ABCA} 1$ protein, the liver $\mathrm{X}$ receptor (LXR) and ApoE mRNA were measured using Western blot and quantitative real-time PCR (QT-PCR) analyses, respectively.

\section{Materials and methods Materials}

Cholesterol was purchased from Aladdin Reagents (Shanghai Jingchun Chemical Co Ltd, Shanghai, China). Streptozotocin was supplied by Sigma-Aldrich (St Louis, MO, USA). The internal standard stigmasterol was supplied by Acros Organics (Geel, Belgium). The 7a-hydroxycholesterol (7a-HC) was supplied by Toronto Research Chemicals (TRC; Ontario, Canada). Water was purified using a Milli-Q system (Millipore, Bedford, MA, USA). All other chemicals were of HPLC grade and commercially available.

\section{Animals}

Male Sprague-Dawley (SD) rats, which weighed 160-170 g, were supplied by SLAC Laboratory Animals (Shanghai, China). The rats were maintained in an air-conditioned animal facility at a temperature of $22 \pm 2{ }^{\circ} \mathrm{C}$ and a relative humidity of $50 \% \pm 10 \%$ on a 12 -h day/night cycle. A standard commercial rodent diet (Xietong BioTech, Nanjing, China) and water were provided ad libitum. The animals were acclimatized to the facilities for $5 \mathrm{~d}$ and fasted with free access to water for $8 \mathrm{~h}$ prior to experimentation. All animal experiments were approved by the Animal Ethics Committee of China Pharmaceutical University.

\section{Diabetic rats induced by STZ}

Diabetes was induced in the rats by an intraperitoneal administration of $65 \mathrm{mg} / \mathrm{kg}$ of STZ dissolved in sodium citrate buffer ( $\mathrm{pH} 4.5)$. The age-matched normal rats only received the vehicle (sodium citrate buffer, $\mathrm{pH} 4.5$ ). On d 7 post-STZ injection, the fasting blood glucose levels were measured using a commercially available glucose kit (Rongsheng BioTech Co Ltd, Shanghai, China) based on the glucose oxidase method. Rats with fasting blood glucose levels in excess of 11.1 $\mathrm{mmol} / \mathrm{L}$ were considered to be diabetic and were included in subsequent experiments.

\section{Animal experiments}

All the animal experiments were conducted on d 35 after the injection of STZ or vehicle. Rats were euthanized under ether anesthesia after an 8-h fast. Blood and the tissues closely related to diabetic symptoms and cholesterol metabolism, including the heart, liver, intestine, kidney, pancreas, cerebral cortex and hippocampus, were immediately collected. Serum samples were obtained for the analysis of biochemical parameters, including triglycerides, insulin, HDL cholesterol, glucose, total cholesterol (TC), free cholesterol (FC) and its metabolite $7 \mathrm{a}-\mathrm{HC}$. Tissues were used for the determination of TC, FC and insulin levels using Western blot and QT-PCR analyses. The levels of serum triglycerides and HDL cholesterol were measured using colorimetric kits (Beijing BHKT
Clinical Reagent Co, Ltd, Beijing, China). Serum glucose levels were measured using a glucose oxidase method kit. The levels of insulin in the serum and tissues were measured by an insulin radioimmunoassay (RIA) kit (Beijing North Institute of Biological Technology, Beijing, China) according to the manufacturer's protocol. Tissues were weighed and homogenized in equal volumes of $50 \mathrm{mmol} / \mathrm{L} \mathrm{NaH}_{2} \mathrm{PO}_{4}$ and $50 \mathrm{mmol} / \mathrm{L}$ $\mathrm{Na}_{2} \mathrm{HPO}_{4}$ buffer containing $1 \%$ bovine serum albumin $(\mathrm{pH}$ 7.4). An aliquot of $100 \mu \mathrm{L}$ of tissue homogenate or serum was used for the determination of insulin levels.

\section{Determination of TC, $\mathrm{FC}$ and $7 \alpha-\mathrm{HC}$ levels in serum and tissues}

The levels of cholesterol in the serum and tissues were measured using the HPLC method ${ }^{[11]}$. The levels of cholesterol were represented as FC (prior to hydrolysis) and TC (after hydrolysis). The tissues were weighed and homogenized in $(1: 10)$ cold saline $(w / v)$ under an ice-bath condition. The homogenates were diluted using saline when necessary. For the measurement of TC, $50 \mu \mathrm{L}$ of serum or tissue homogenate was hydrolyzed in a $50^{\circ} \mathrm{C}$ water bath for $2 \mathrm{~h}$ in $500 \mu \mathrm{L}$ of alcoholic potassium hydroxide solution $[33 \% \mathrm{KOH} /$ ethanol $(6 / 94, v / v)]^{[12]}$. A $50-\mu \mathrm{L}$ aliquot of the hydrolyzed mixture was extracted with $1 \mathrm{~mL}$ of $\mathrm{n}$-hexane by vortexing for $5 \mathrm{~min}$. For the measurement of $\mathrm{FC}$, unhydrolyzed serum or tissue homogenates were subjected to the same extraction method. After centrifugation at $2000 \times g$ for $5 \mathrm{~min}, 400 \mu \mathrm{L}$ of the upper organic layer was transferred to a tube containing $200 \mathrm{ng}$ of stigmasterol (internal standard) and evaporated to dryness under nitrogen. The residues were reconstituted in $400 \mu \mathrm{L}$ of acetone and subjected to Jones oxidation ${ }^{[11]}$. Briefly, the samples were treated with a derivative agent (equal volumes of $2 \mathrm{~mol} / \mathrm{L}$ chromic acid and $2 \mathrm{~mol} / \mathrm{L}$ sulfuric acid) in acetone for $5 \mathrm{~min}$ in a $25^{\circ} \mathrm{C}$ water bath. At the end of the reaction, $550 \mu \mathrm{L}$ of water was added. The derivative of cholesterol was extracted with n-hexane, dried under nitrogen and reconstituted in $200 \mu \mathrm{L}$ of methanol. After centrifugation, $20 \mu \mathrm{L}$ of the supernatant was injected into a Shimadzu LC-10Avp system (Shimadzu, Japan) consisting of an LC-10Avp liquid chromatographic pump, a Shimadzu VP-ODS column $(5.0 \mu \mathrm{m} ; 150 \mathrm{~mm} \times 4.6 \mathrm{~mm}$ id) and an SPD-10Avp ultraviolet detector operating at a wavelength of $250 \mathrm{~nm}$. The mobile phase consisted of methanol/water $(98 / 2, v / v)$. The flow rate was maintained at $1.0 \mathrm{~mL} / \mathrm{min}$. The derivative of cholesterol was stable within the analyzing time ranges $(24 \mathrm{~h})$, and the recovery was larger than $80 \%$. The linearity of free cholesterol was between $3.9 \mu \mathrm{g} / \mathrm{mL}$ and 250 $\mu \mathrm{g} / \mathrm{mL}$ while that of total cholesterol was between $15.6 \mu \mathrm{g} / \mathrm{mL}$ and $1.0 \mathrm{mg} / \mathrm{mL}$.

The levels of $7 \mathrm{a}-\mathrm{HC}$ in serum were measured using the liquid chromatography mass spectrometry (LC-MS) method according to a previously described method ${ }^{[13]}$ with minor modifications. Briefly, $200 \mu \mathrm{L}$ of serum was saponified in 0.5 $\mathrm{mL}$ of $1 \mathrm{~mol} / \mathrm{L}$ ethanolic $\mathrm{NaOH}$ for $1 \mathrm{~h}$ at $37^{\circ} \mathrm{C}$ in a shaking water bath. The mixture was extracted by adding $1 \mathrm{~mL}$ of n-hexane and isopropyl alcohol $(9: 1, v / v)$ and vortexing for 5 min. After centrifugation at $2000 \times g$ for $5 \mathrm{~min}, 0.8 \mathrm{~mL}$ of the upper organic layer was transferred to a tube containing 100 
ng of stigmasterol as an internal standard and evaporated to dryness under nitrogen. The residues were then reconstituted in $100 \mu \mathrm{L}$ of methanol, which was followed by centrifugation at $37000 \times g$ for $10 \mathrm{~min}$. An aliquot of $10 \mu \mathrm{L}$ was injected into the LC-MS system.

LC separation was achieved on a Shimadzu VP-ODS column (5.0 $\mu \mathrm{m} ; 150 \mathrm{~mm} \times 4.6 \mathrm{~mm}$ id; Shimadzu, Japan) maintained at $40^{\circ} \mathrm{C}$. The mobile phase consisted of methanol and water $(98: 2)$, and the flow rate was maintained at $1.0 \mathrm{~mL} / \mathrm{min}$. The effluent from the HPLC column was directed into an atomic pressure chemical ionization (APCI) probe. The mass spectrometer conditions were optimized to obtain maximal sensitivity. The optimized APCI conditions employed included a DL temperature of $250^{\circ} \mathrm{C}$ and an interface temperature of $350^{\circ} \mathrm{C}$, and the heating block temperature was maintained at $250^{\circ} \mathrm{C}$. The nebulizing and drying gas were maintained at 4 $\mathrm{L} / \mathrm{min}$ and $10 \mathrm{~L} / \mathrm{min}$, respectively. The selected ion monitoring (SIM) including a series of ions with $\mathrm{m} / \mathrm{z} 385.35$, and $395.4\left[\mathrm{M}+\mathrm{H}-\mathrm{H}_{2} \mathrm{O}\right]^{+}$that corresponded to $7 \mathrm{a}-\mathrm{HC}$ and internal standard (IS) was used for the quantitative analysis. The data were acquired, processed and analyzed by Lab Solutions chromatographic software (Shimadzu, Japan). An assay validation was carried out. No matrix effect was observed for either $7 \mathrm{a}-\mathrm{HC}$ or the IS. The intra-day relative standard deviation of $7 \mathrm{a}-\mathrm{HC}$ was lower than $5 \%$. The linear range of $7 \mathrm{a}-\mathrm{HC}$ in the serum was between $31.25 \mathrm{ng} / \mathrm{mL}$ and $250 \mathrm{ng} / \mathrm{mL}$. The lowest limit for the quantification of $7 \mathrm{a}-\mathrm{HC}$ in the serum was 31.25 $\mathrm{ng} / \mathrm{mL}$.

\section{Western blot analysis}

Western blot analysis was used for quantification of the ABCA1 protein in the tissues. Briefly, tissues were weighed and homogenized in RIPA (radioimmunoprecipitation) buffer (Applygen Technologies Inc, Beijing, China). The protein concentration was determined by the Bio-Rad Protein Assay (BioRad Labs, Richmond, CA, USA). Different amounts of protein $(120,80,100,100,80,80$, and $160 \mu \mathrm{g}$ for the intestine, liver, hippocampus, cerebral cortex, kidney, heart and pancreas, respectively) were separated by SDS-PAGE and transferred to polyvinylidene difluoride (PVDF) membranes. ABCA1 was detected using a rabbit anti-rat monoclonal ABCA1 antibody (Abcam, USA) as the primary antibody and horseradish peroxidase (HRP)-conjugated goat anti-rabbit IgG (GeneScript, Nanjing, China) as the secondary antibody. Anti-GAPDH (GeneScript, Nanjing, China) was used as an internal proteinloading control. Detection of the ABCA1 protein band was performed with an enhanced chemiluminescence (ECL) kit (Haigene, Harbin, China), and the densitometry of the subsequent images were analyzed by ImageJ software (Bio-Rad, Hercules, USA).

\section{QT-PCR analysis}

For a quantitative comparison of the LXR- $\alpha, \mathrm{LXR}-\beta$, and ApoE mRNA levels, QT-PCR was performed using SYBR Green fluorescence. Total RNA was extracted with TRIzol reagent (SunShineBio, Nanjing, China) from frozen tissues according to the manufacturer's instructions. The primers for the LXR- $\alpha$, LXR$\beta$, and ApoE sequences are listed in Table 1 . The RNA concentration was quantified by spectrophotometry at $260 \mathrm{~nm}$. Total RNA from each original sample was converted into cDNA, and QT-PCR was performed in a PTC-200 Thermo Cycler (MJ Research, Waltham, USA) according to the manufacturer's protocols. The amplification was performed in a $26.5-\mu \mathrm{L}$ reaction mixture that consisted of the following: $12.5 \mu \mathrm{L}$ of qPCR Master Mix (Promega, Madison, WI, USA), $2.0 \mu \mathrm{L}$ of $10 \times$ cDNA, $2.5 \mu \mathrm{L}$ of $2 \mu \mathrm{mol} / \mathrm{L}$ forward and reverse primers and $9.5 \mu \mathrm{L}$ of nuclease-free water. Each assay was performed in triplicate with $\beta$-actin mRNA as the endogenous control. The QT-PCR thermal cycling parameters were an initial denaturation for $2 \mathrm{~min}$ at $95^{\circ} \mathrm{C}$ that was followed by 40 cycles at $95^{\circ} \mathrm{C}$ for $5 \mathrm{~s}$ and $60^{\circ} \mathrm{C}$ for $30 \mathrm{~s}$. Melting curves were performed to investigate the specificity of the PCR reaction. Relative quantification (RQ) of each gene expression was calculated according to the comparative $\mathrm{Ct}$ method using the formula: $\mathrm{RQ}=2^{-\Delta \mathrm{Ct}[14]}$.

Table 1. Primer sequences for QT-PCR.

\begin{tabular}{lllc}
\hline DNA amplified & \multicolumn{2}{c}{ Primer sequence $5^{\prime} \rightarrow 3^{\prime}$} & Size (bp) \\
\hline LXR- $\alpha$ & $\begin{array}{l}\text { Sense } \\
\text { Antisense }\end{array}$ & $\begin{array}{l}\text { AGCAACAGTGTAACAGGCGCT } \\
\text { GTGCAATGGCCAAGG }\end{array}$ & 63 \\
LXR- $\beta$ & Sense & CAACCACGAGACAGAGTGCATCA & 122 \\
& Antisense & GCATAGCCCGAGAGACTCAAAG & \\
Apo E & Sense & ACCGCTTCTGGGATTACCTGC & 129 \\
& Antisense & ATGCCTTTACTTCCGTCATAGTGTC & \\
$\beta$-Actin & Sense & GGGAATCGTGCGTGACATT & 76 \\
& Antisense & GCGGCAGTGGCCATCTC & \\
\hline
\end{tabular}

\section{Statistical analysis}

The data are presented as the mean \pm standard deviation (SD). Statistical comparisons were made using the 2-tailed Student's $t$-test. A $P$ value less than 0.05 was considered significant.

\section{Results}

\section{Biochemical parameters in STZ-induced diabetic rats}

STZ-induced diabetes is a well-documented model of experimental T1DM ${ }^{[15]}$. As expected, a single administration of STZ to rats produced diabetic symptoms, including polyphagia, polyuria, polydipsia and a loss of body weight. Biochemical parameters in the serum of the STZ-induced rats and normal rats were obtained (Table 2). It was found that diabetes dramatically increased the serum levels of glucose, FC, TC, and triglycerides, which was accompanied by a low level of insulin. Diabetes also significantly elevated the level of 7a-HC, which is a metabolite of cholesterol. The levels of HDL cholesterol in the serum of diabetic rats showed a tendency to decrease, but no significance was observed.

\section{Cholesterol content in tissues of STZ-induced diabetic rats}

The cholesterol content in the intestine, heart, kidney, liver, 
Table 2. Serum biochemical parameters of rats 5 weeks after injection of STZ. Mean \pm SD. $n=6$. ${ }^{\mathrm{b}} P<0.05$ vs control rats.

\begin{tabular}{lcc}
\hline \multicolumn{1}{c}{ Parameters } & Control & Diabetes \\
\hline Initial body weight $(\mathrm{g})$ & $162.8 \pm 2.5$ & $171.4 \pm 2.3^{\mathrm{b}}$ \\
Final body weight $(\mathrm{g})$ & $361.0 \pm 25.8$ & $210.8 \pm 23.0^{\mathrm{b}}$ \\
Glucose $(\mathrm{mmol} / \mathrm{L})$ & $6.10 \pm 0.52$ & $20.52 \pm 3.22^{\mathrm{b}}$ \\
Triglycerides $(\mathrm{mmol} / \mathrm{L})$ & $2.50 \pm 0.60$ & $3.28 \pm 0.37^{\mathrm{b}}$ \\
$\mathrm{HDL}$ cholesterol $(\mathrm{mg} / \mathrm{mL})$ & $0.40 \pm 0.06$ & $0.36 \pm 0.04$ \\
Insulin $(\mathrm{mlU} / \mathrm{mL})$ & $0.07 \pm 0.01$ & $0.04 \pm 0.002^{\mathrm{b}}$ \\
Free cholesterol $(\mu \mathrm{g} / \mathrm{mL})$ & $27.36 \pm 8.96$ & $65.83 \pm 27.65^{\mathrm{b}}$ \\
Total cholesterol $(\mathrm{mg} / \mathrm{mL})$ & $0.81 \pm 0.1$ & $1.51 \pm 0.51^{\mathrm{b}}$ \\
$7 \alpha$-hydroxycholesterol $(\mathrm{ng} / \mathrm{mL})$ & $106.20 \pm 43.81$ & $237.23 \pm 94.30^{\mathrm{b}}$ \\
\hline
\end{tabular}

hippocampus, cerebral cortex and pancreas of STZ-induced diabetic rats was measured (Figure 1). The levels of cholesterol are presented as FC and TC. The results showed that the cholesterol in tissues existed mainly as TC. High levels of TC were observed in the hippocampus $(16.2 \mathrm{mg} / \mathrm{g}$ tissue $)$ and cerebral cortex $(36.4 \mathrm{mg} / \mathrm{g}$ tissue). Only a small portion of cholesterol existed as FC in most tissues. For example, the free fractions of cholesterol in the hippocampus and cerebral cortex were less than $1 \%$. Interestingly, the pancreas and heart had lower contents of TC $(1.5 \mathrm{mg} / \mathrm{g}$ in the heart and $3.9 \mathrm{mg} / \mathrm{g}$ in the pancreas) but showed high concentrations of FC (146.5 $\mathrm{mg} / \mathrm{g}$ in the heart and $310.9 \mathrm{mg} / \mathrm{g}$ in the pancreas), which resulted in fractions of FC in the two tissues of $9.8 \%$ and $7.9 \%$,
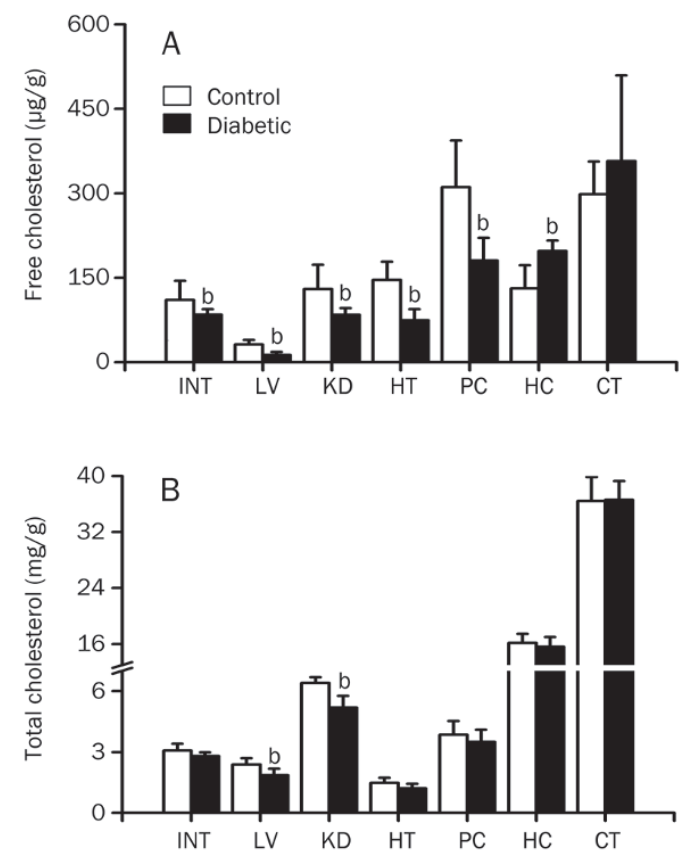

Figure 1. The levels of free cholesterol (A) and total cholesterol (B) in the intestine (INT), liver (LV), kidney (KD), heart (HT), pancreas (PC), hippocampus $(\mathrm{HC}$ ) and cerebral cortex (CT) of control rats (white bars) and diabetic rats (black bars). Cholesterol was determined by HPLC analysis. Values are expressed as the mean $\pm \mathrm{SD}(n=6)$. ${ }^{\mathrm{b}} P<0.05$ vs control rats. respectively.

Diabetes significantly decreased the levels of FC in the peripheral tissues. Diabetes also decreased the TC level in peripheral tissues, but significance was only found for the kidney and liver. The extent of decreased levels of FC was greater than that of TC in the corresponding tissues, which indicated that FC was more sensitive to diabetes. In contrast, diabetes increased the levels of FC in both the hippocampus and cerebral cortex. A significant increase $(50.4 \%)$ was found in the hippocampi of diabetic rats, but the cerebral cortex $(19.8 \%)$ only showed a tendency to increase.

\section{Insulin levels in tissues of STZ-induced diabetic rats}

Insulin levels in the tissues of diabetic rats were assayed using the RIA method (Table 3). The results showed that the effects of diabetes on the insulin levels in tissues were tissuedependent. Diabetes significantly reduced the insulin levels in the liver, pancreas and intestine, resulting in a $38.5 \%, 33.0 \%$, and $63.0 \%$ decrease, respectively, compared with the levels in normal rats. However, the insulin levels in the kidney, heart, hippocampus and cerebral cortex of STZ-induced diabetic rats remained unchanged or only slightly decreased.

Table 3. Tissue insulin levels in control and STZ-induced diabetic rats. Insulin was determined by RIA method. Mean \pm SD. $n=6$. ${ }^{b} P<0.05$ vs control rats.

\begin{tabular}{lcc}
\hline Insulin $(\mathrm{mlU} / \mathrm{g})$ & Control & Diabetes \\
\hline Liver & $1.54 \pm 0.23$ & $0.94 \pm 0.07^{\mathrm{b}}$ \\
Intestine & $4.12 \pm 0.92$ & $1.52 \pm 0.61^{\mathrm{b}}$ \\
Kidney & $1.28 \pm 0.27$ & $1.25 \pm 0.24$ \\
Heart & $0.84 \pm 0.24$ & $0.79 \pm 0.57$ \\
Hippocampus & $1.14 \pm 0.24$ & $1.25 \pm 0.15$ \\
Cortex & $1.02 \pm 0.09$ & $0.94 \pm 0.08$ \\
Pancreas & $645.56 \pm 76.74$ & $432.27 \pm 104.24^{\mathrm{b}}$ \\
\hline
\end{tabular}

Expression of ABCA1 protein in tissues of STZ-induced diabetic rats

$\mathrm{ABCA} 1$ is the rate-controlling transporter in reverse cholesterol transport, which plays the most important role in the maintenance of cellular cholesterol homeostasis ${ }^{[16,17]}$. To investigate whether the alteration in cholesterol in the tissues of diabetic rats came from a change in ABCA1 expression, the levels of the ABCA1 protein in the tissues were measured using Western blot analysis. The results showed that the heart and cerebral cortex exhibited the highest basal expression of the ABCA1 protein (Figure 2). The pancreas showed only a weak basal expression of the ABCA1 protein. The expression of the ABCA1 protein was induced by diabetes. The strongest induction occurred in the pancreas of diabetic rats, which resulted in an 11.7-fold increase compared with normal rats. Diabetes also increased the expression of ABCA1 in the liver, kidney and cerebral cortex to $105.6 \%, 314.5 \%$, and $53.9 \%$, respectively, 
A
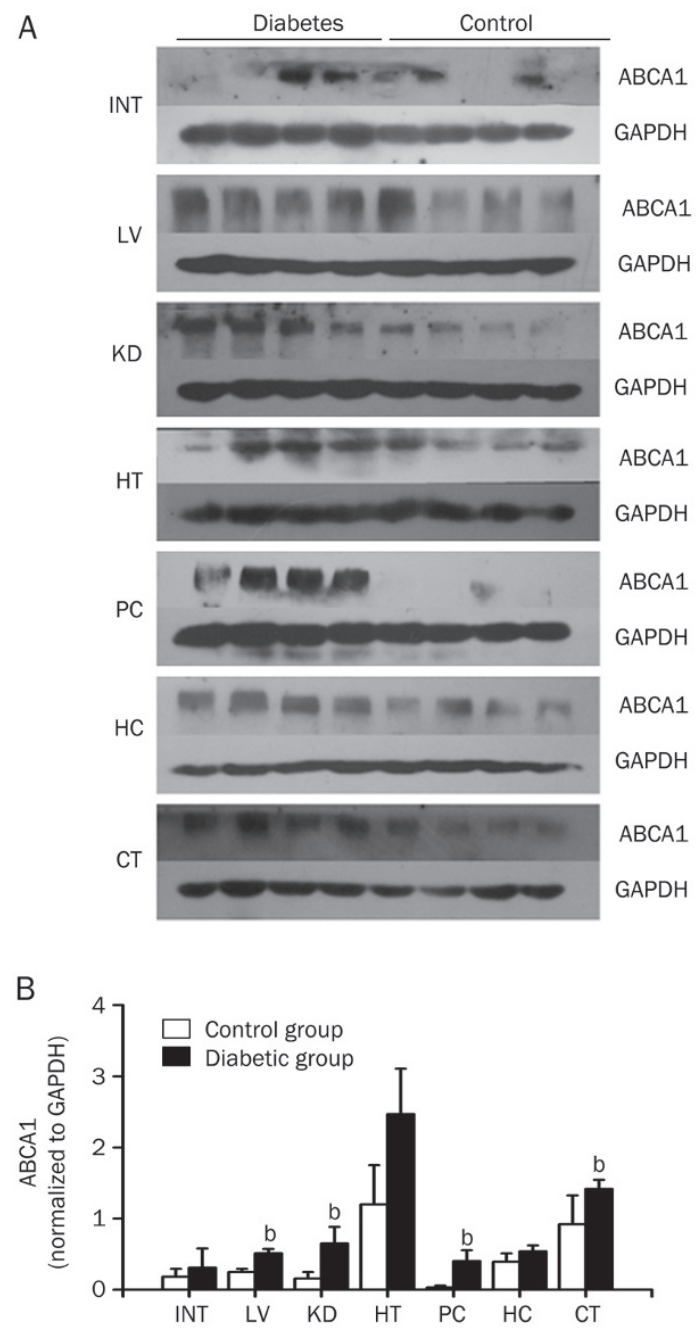

Figure 2. The levels of ABCA1 expression in the intestine (INT), liver (LV), kidney (KD), heart (HT), pancreas (PC), cerebral cortex (CT) and hippocampus $(\mathrm{HC})$ of control rats (white bars) and diabetic rats (black bars). Western blots of $A B C A 1(A)$ and the ratio of relative staining intensity for $A B C A 1(B)$ in the control and STZ-induced diabetic rats are shown. Mean $\pm \operatorname{SD}(n=4)$. ${ }^{\mathrm{b}} P<0.05$ vs control rats.

of the expression in the normal rats. The expression of the ABCA1 protein in the heart of diabetic rats also increased by $105.7 \%$ compared with normal rats, although no significance was observed. The increased expression of the ABCA1 protein in the peripheral tissues was in agreement with decreases in the concentration of cholesterol in the corresponding tissues.

\section{Expression of LXR- $\alpha$, LXR- $\beta$, and ApoE mRNA in tissues of STZ- induced diabetic rats}

It is generally acknowledged that ABCA1 expression in tissues is mainly modulated by the nuclear receptors LXR-a and LXR- $\beta$. The mRNA levels of these genes were measured using QT-PCR. The results showed that the expression of LXR mRNA in the tissues of rats was tissue-dependent and LXR subtype-dependent.

For LXR-a mRNA, the highest expression was observed in the liver, and a modest expression was found in the pancreas, kidney, intestine and heart (Figure 3A). The hippocampus and cerebral cortex showed only a weak expression of LXR-a mRNA. The expression of LXR-a mRNA in the intestine, liver and pancreas tissues was 5-10-fold higher than that of LXR- $\beta$ mRNA in the corresponding tissues. Diabetes significantly induced the LXR-a mRNA levels in the liver, kidney and heart. The strongest induction of LXR- $\alpha$ mRNA was found in the heart of diabetic rats, which showed a 2.64-fold increase compared with normal rats. However, diabetes only marginally increased or did not alter the expression of LXR-a mRNA in the intestine, pancreas, hippocampus and cerebral cortex.

For LXR- $\beta$ mRNA, a lower expression of LXR- $\beta$ mRNA was found in the intestine, liver, heart, kidney and pancreas tissues compared with LXR-a mRNA (Figure 3B). Diabetes signifi-
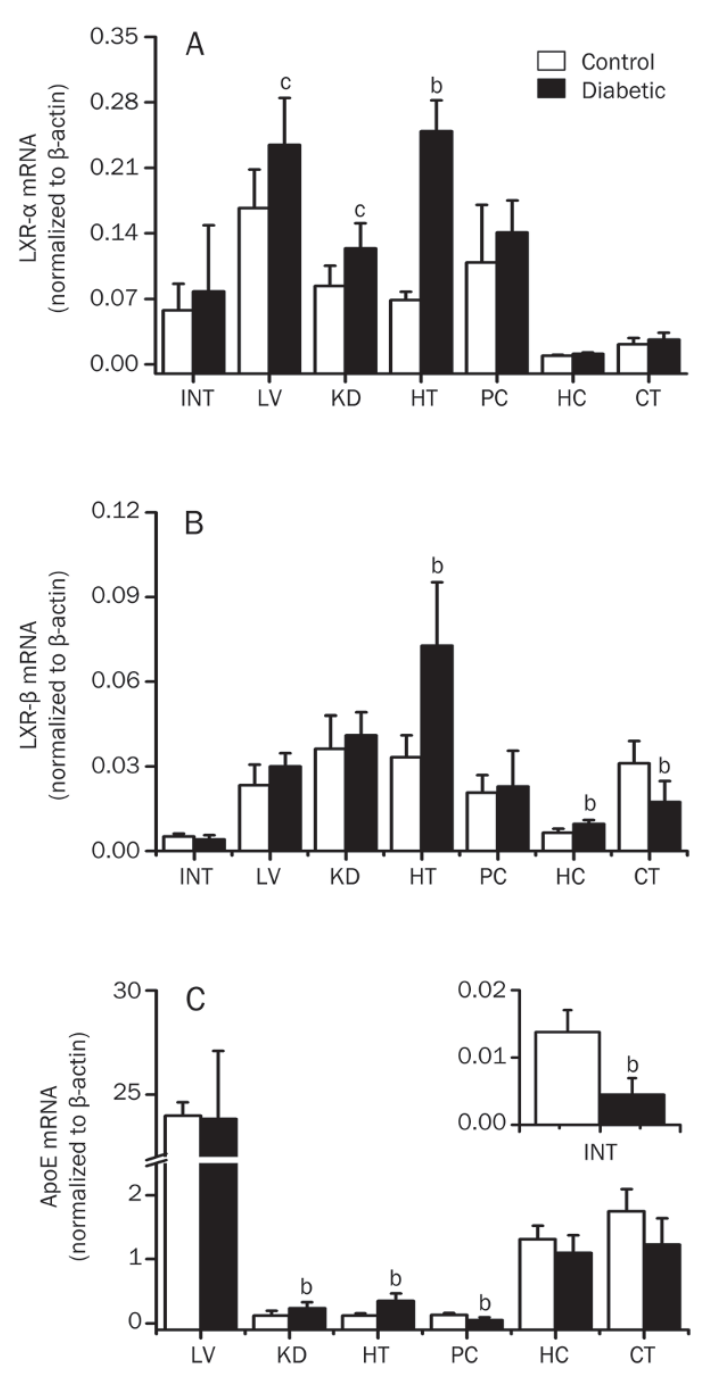

Figure 3. The levels of LXR- $\alpha(A), \operatorname{LXR}-\beta(B)$, and ApoE (C) mRNA in the intestine (INT), liver (LV), kidney (KD), heart (HT), pancreas (PC), cerebral cortex (CT) and hippocampus (HC) of the control rats (white bars) and diabetic rats (black bars). The levels of LXR- $\alpha$, LXR- $\beta$, and ApoE mRNA were determined by QT-PCR analysis, and all values were normalized to the levels of $\beta$-actin mRNA. The data are expressed as $2^{-\mathrm{Act}}$ values of mean $\pm \operatorname{SD}(n=4)$. ${ }^{\mathrm{b}} P<0.05,{ }^{\mathrm{c}} P<0.01$ versus control rats. 
cantly elevated the expression of LXR- $\beta$ mRNA in the heart and hippocampus and decreased the expression of LXR- $\beta$ mRNA in the cerebral cortex. However, diabetes did not affect the expression of the gene in other tissues. Similar to LXR- $\alpha$ mRNA, the strongest induction of LXR- $\beta$ mRNA occurred in the heart of diabetic rats, which showed a 1.18-fold increase compared with control rats.

It is generally accepted that ApoE, the main apolipoprotein in the brain, is crucial for brain cholesterol homeostasis ${ }^{[18-21]}$. The levels of ApoE mRNA in the indicated tissues were measured, and the results showed a high expression of ApoE mRNA in the liver, hippocampus and cerebral cortex (Figure 3C). Other tissues showed only a low level of ApoE mRNA. Diabetes significantly increased the levels of ApoE mRNA in the kidney and heart and decreased the mRNA levels in the pancreas and intestine. Diabetes also decreased the ApoE mRNA level in the hippocampus (16.3\%) and cerebral cortex $(29.9 \%)$, although no significance was observed.

\section{Discussion}

The main findings of this study were that the effects of diabetes on the cholesterol content in the brain and peripheral tissues were different. Diabetes increased the FC levels in the hippocampus and cerebral cortex without altering the TC content but decreased both the FC and TC levels in the liver, kidney, heart, intestine and pancreas. It is noteworthy that the magnitude of tissue TC level changes under diabetic conditions was smaller than that of the serum FC and TC levels. This may derive from the fact that the serum cholesterol existed almost exclusively in a rapidly exchangeable pool, while the tissue cholesterol consisted of both a slowly exchanging pool and a nonexchangeable pool ${ }^{[22,23]}$, which made the serum cholesterol more susceptible to diabetes than the tissue cholesterol.

Several reports have shown that diabetes increases the TC levels in the liver, kidney and heart of type 2 diabetic rats ${ }^{[24,25]}$, which is in contrast with the present findings. The quantitative method used in these studies may be an important reason for the differences. The method ${ }^{[24,25]}$ used in these studies was that the reaction of cholesterol in the presence of an $\mathrm{FeCl}_{3}$ $\mathrm{H}_{3} \mathrm{PO}_{4}-\mathrm{H}_{2} \mathrm{SO}_{4}$ mixture forms a colored complex, which was measured using spectrophotometer. A previous study proved that other sterols might interfere with the quantification of cholesterol by this method, thus resulting in large errors ${ }^{[26]}$. Another report also showed that the colorimetric method would generate a value roughly $50 \%$ higher than other methods $^{[27]}$. All the results indicated that the selectivity and accuracy of the colorimetric method was inferior to the HPLC method that was used in the present study. In addition, STZinduced type 1 diabetes is characterized by an insulin deficiency, suggesting that the lack of insulin may also be one of the reasons for the discrepancies.

It has generally been accepted that ABCA1 is a key transporter of cholesterol efflux. The present study showed that diabetes increased the ABCA1 protein level in peripheral tissues, which suggested that the decreased FC and TC content was partly due to increases in the expression of ABCA1. How- ever, other reports describing the expression of the ABCA1 protein under diabetic states are often controversial. A study using virus-induced diabetic mice and type 1 non-obese diabetic mice ${ }^{[10]}$ showed that diabetes slightly increased the expression of $A B C A 1$ in liver, decreased $A B C A 1$ protein levels in peritoneal macrophages and kidney, and did not affect the ABCA1 protein level in the brain. Another study ${ }^{[28]}$ showed that the expression of ABCA1 mRNA was decreased in the liver and peritoneal macrophages of STZ-induced diabetic mice. There was also a report showing that the expression of ABCA1 mRNA increased in the aorta of insulin-insufficient mice $^{[9]}$, which was consistent with our findings. All these results infer that the differences in ABCA1 expression under diabetic conditions might derive from the methodology, animal models, type of diabetes and its duration.

Elevated expression of the ABCA1 protein was also found in the hippocampus and cerebral cortex of diabetic rats, but this did not explain the fact that the levels of FC increased. It is not clear what mechanisms are responsible for increasing the FC levels in the hippocampus and cerebral cortex. ApoE is considered to be a major apolipoprotein for cholesterol transport and clearance in the brain ${ }^{[18-21]}$. The data from QT-PCR showed that apart from the liver, the peripheral tissues exhibited a low level of ApoE mRNA, which was in accordance with the fact that the liver is the primary organ for $\mathrm{ApoE}$ secretion $^{[29]}$. Contrary to the low expression of ApoE mRNA in all the studied peripheral tissues except the liver, high levels of ApoE mRNA were found in the hippocampus and cerebral cortex. Further study showed that diabetes decreased ApoE mRNA in the hippocampus and cerebral cortex by $16.3 \%$ and $29.9 \%$, respectively, although no significance was found. Similar phenomena were also observed in alloxan-induced diabetic rabbits ${ }^{[30]}$. This indicated that the suppression of ApoE mRNA might at least partly contribute to the increased FC content under diabetic states. Other mechanisms may also be involved in the regulation of cholesterol homeostasis in the brain. All cholesterol input into the central nervous system comes from de novo synthesis ${ }^{[31]}$. A small excess of cholesterol is exported into the circulation to maintain cholesterol homeostasis in the brain. Two mechanisms are involved in this process. One is reverse cholesterol transport, which is mediated by $\mathrm{ABC}$ transporters, the class A scavenger receptor and ApoE. The other important pathway is the conversion of cholesterol into oxysterols ${ }^{[32]}$. In contrast to cholesterol, oxysterols are able to traverse the blood-brain barrier. These facts suggest that alterations in these factors may contribute to the increased levels of cholesterol in the brain of diabetic rats. In addition, oxidative stress may also be involved in the elevated brain cholesterol levels under diabetic conditions ${ }^{[33]}$. Further studies are still needed to elucidate this issue.

This study showed that diabetes increased the expression of the ABCA1 protein in the indicated tissues, but the underlying mechanism is not clear. A report showed that insulin could enhance the degradation of ABCA1 and downregulate its activity by promoting the phosphorylation of the protein ${ }^{[34]}$, which suggested that an insulin deficiency may be one of the 
causes for increased ABCA1 protein levels under diabetic states. LXRs were considered to be the most important nuclear receptors responsible for the regulation of ABCA1. Although LXR- $\beta$ is indispensable for the expression of $A B C A 1^{[35]}$, some studies indicated a more important role for LXR- $\alpha$ in the regulation of $\mathrm{ABCA1} 1^{[36,37]}$. The QT-PCR results showed that diabetes induced LXR-a mRNA, which could be one of the reasons for the increased ABCA1 protein levels.

In addition, other proteins, including sterol regulatory element- $\beta$ inding protein-2 (SREBP-2) and 3-hydroxy-3methylglutaryl coenzyme A reductase (HMGCR), may also be involved in the regulation of cholesterol homeostasis ${ }^{[38,39]}$. A report showed that diabetes may decrease both SREBP-2 and HMGCR mRNA in the liver of rats, and insulin partially reversed the alterations induced by diabetes ${ }^{[40]}$. Insulin is considered to be a potent inducer of $\mathrm{HMGCR}^{[41]}$. Insulin treatment increased the HMGCR activity in hepatic microsomes of STZ-induced diabetic rats ${ }^{[22]}$. Data from Caco-2 cells demonstrated that a high glucose level might also decrease the SREBP-2 protein level and HMGCR activity ${ }^{[43]}$. All these results indicate that SREBP-2 and HMGCR may play a role in imbalanced cholesterol levels, although there are contradictory reports ${ }^{[31,44]}$. These discrepancies may be a result of animal model differences and disease duration.

Oxysterols are considered to be the endogenous ligands of LXRs, and we used 7a-HC, which is formed by cholesterol7-hydroxylase (CYP7A1), as a marker for oxysterols. It was found that diabetes increased the serum 7a-HC level by 1.28fold compared with normal rats. The increased oxysterol levels could further enhance LXR activities, resulting in elevated $\mathrm{ABCA} 1$ protein expression in peripheral tissues. In addition, CYP7A1 is the rate-limiting enzyme in the synthesis of bile acids ${ }^{[45]}$. Elevated $7 \mathrm{a}-\mathrm{HC}$ levels also suggested that enhanced cholesterol metabolism may constitute one of the reasons for the reduced liver cholesterol levels.

Cholesterol is one of the major constituents of the plasma membrane. Intact plasma membrane microdomains are critical for maintaining cell viability and function. The reduction of cholesterol in peripheral tissues, especially in heart and kidney, may be associated with diabetic nephropathy and diabetic cardiomyopathy. A report showed that both cholesterol esterase and cholesterol oxidase caused marked cytotoxicity by perturbing the plasma membrane cholesterol in normal mouse proximal tubular segments. A further study demonstrated that disturbing lipid raft microdomains with cholesterol esterase dramatically increased the tubule susceptibility to Fe-mediated oxidative stress and $\mathrm{Ca}^{2+}$ overloading ${ }^{[46]}$. Cholesterol depletion using cyclodextrins also resulted in reduced HEK293A cell viability and increased lactate dehydrogenase levels, which were accompanied by membrane damage, apoptosis and necrosis ${ }^{[47]}$. A recent study showed that cholesterol depletion using methyl- $\beta$ eta-cyclodextrin $(\mathrm{M}-\beta-\mathrm{CD})$ modulated the basal L-type $\mathrm{Ca}^{2+}$ current and abolished its adrenergic enhancement in ventricular myocytes ${ }^{[48]}$. $\mathrm{Ca}^{2+}$-activated $\mathrm{Cl}^{-}$ currents were augmented by $\mathrm{M}-\beta-\mathrm{CD}$ in murine portal vein myocytes ${ }^{[49]}$. Basolateral membrane cholesterol extraction with
M- $\beta$-CD also reduced the $\mathrm{Na}^{+} / \mathrm{K}^{+}$pump activity in A6 renal epithelia ${ }^{[50]}$. In addition, some reports showed that cholesterol depletion suppressed insulin secretion ${ }^{[51-53]}$, and decreased cholesterol levels in the pancreas may contribute to the severity of diabetes.

In summary, type 1 diabetes decreased the levels of both free and total cholesterol in peripheral tissues but increased the FC levels in the hippocampus without altering the TC level. The decreased free cholesterol levels in the peripheral tissues may be partly due to an increased expression of the ABCA1 protein.

\section{Acknowledgements}

This work was supported by the National Science Foundation of China (Grants № 30873123 and 39970862) and the Funding for Innovative Research Team in the Institution of Jiangsu Higher Education.

\section{Author contribution}

All of the authors guarantee the integrity of the study. Xinting WANG, Li LIU, and Xiao-dong LIU designed the study; Xin-ting WANG, Jia LI, Nan HU, and Shi JIN conducted the animal experiments; Jia LI and Can LIU carried out the other detailed research work; Dan MEI interpreted the data; Xinting WANG and Xiao-dong LIU wrote the manuscript. The final version was approved by all of the authors.

\section{References}

1 Wadwa RP, Kinney GL, Maahs DM, Snell-Bergeon J, Hokanson JE, Garg SK, et al. Awareness and treatment of dyslipidemia in young adults with type 1 diabetes. Diabetes Care 2005; 28: 1051-6.

2 Miyazaki A, Sakashita N, Lee O, Takahashi K, Horiuchi S, Hakamata H, et al. Expression of ACAT-1 protein in human atherosclerotic lesions and cultured human monocytes-macrophages. Arterioscler Thromb Vasc Biol 1998; 18: 1568-74.

3 Paulson KE, Zhu S-N, Chen M, Nurmohamed S, Jongstra-Bilen J, Cybulsky MI. Resident intimal dendritic cells accumulate lipid and contribute to the initiation of atherosclerosis. Circ Res 2010; 106: 383-90.

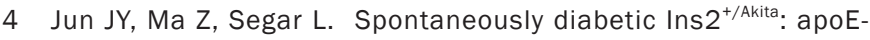
deficient mice exhibit exaggerated hypercholesterolemia and atherosclerosis. Am J Physiol Endocrinol Metab 2011; 301: E145-54.

5 James SH, Meyers AM. Microangiopathic hemolytic anemia as a complication of diabetes mellitus. Am J Med Sci 1998; 315: 211-5.

$6 \mathrm{Hu} \mathrm{G}$, Antikainen R, Jousilahti P, Kivipelto M, Tuomilehto J. Total cholesterol and the risk of Parkinson disease. Neurology 2008; 70 : 1972-9.

7 Hartmann T. Cholesterol, A $\beta$ and Alzheimer's disease. Trends Neurosci 2001; 24: S45-8.

8 Luo DX, Cao DL, Xiong Y, Peng XH, Liao DF. A novel model of cholesterol efflux from lipid-loaded cells. Acta Pharmacol Sin 2010; 31: 1243-57.

9 Calkin AC, Forbes JM, Smith CM, Lassila M, Cooper ME, JandeleitDahm KA, et al. Rosiglitazone attenuates atherosclerosis in a model of insulin insufficiency independent of its metabolic effects. Arterioscler Thromb Vasc Biol 2005; 25: 1903-9.

10 Tang C, Kanter JE, Bornfeldt KE, Leboeuf RC, Oram JF. Diabetes reduces the cholesterol exporter $\mathrm{ABCA} 1$ in mouse macrophages and 
kidneys. J Lipid Res 2010; 51: 1719-28.

11 Dong J, Chen W, Wang S, Zhang J, Li H, Guo H, et al. Jones oxidation and high performance liquid chromatographic analysis of cholesterol in biological samples. J Chromatogr B 2007; 858: 239-46.

12 Abell LL, Levy BB, Brodie BB, Kendall FE. A simplified method for the estimation of total cholesterol in serum and demonstration of its specificity. J Biol Chem 1952; 195: 357-66.

13 Honda A, Yamashita K, Hara T, Ikegami T, Miyazaki T, Shirai M, et al. Highly sensitive quantification of key regulatory oxysterols in biological samples by LC-ESI-MS/MS. J Lipid Res 2009; 50: 350-7.

14 Livak KJ, Schmittgen TD. Analysis of relative gene expression data using real-time quantitative PCR and the $2^{-\Delta \Delta C T}$ method. Methods 2001; 25: 402-8.

15 Liu H, Xu X, Yang Z, Deng Y, Liu X, Xie L. Impaired function and expression of P-glycoprotein in blood-brain barrier of streptozotocininduced diabetic rats. Brain Res 2006; 1123: 245-52.

16 Oram JF, Lawn RM, Garvin MR, Wade DP. ABCA1 is the CAMPinducible apolipoprotein receptor that mediates cholesterol secretion from macrophages. J Biol Chem 2000; 275: 34508-11.

17 Li D, Wang D, Wang Y, Ling W, Feng X, Xia M. Adenosine monophosphate activated protein kinase induces cholesterol efflux from macrophage-derived foam cells and alleviates atherosclerosis in Apolipoprotein E-deficient mice. J Biol Chem 2010; 285: 33499-509.

18 Rahman SMA, Van Dam AM, Schultzberg M, Crisby M. High cholesterol diet results in increased expression of interleukin- 6 and caspase-1 in the brain of apolipoprotein E knockout and wild type mice. J Neuroimmunol 2005; 169: 59-67.

19 Vance JE, Hayashi H. Formation and function of apolipoprotein E-containing lipoproteins in the nervous system. Biochim Biophys Acta 2010; 1801: 806-18.

20 Hayashi $\mathrm{H}$. Lipid metabolism and glial lipoproteins in the central nervous system. Biol Pharm Bull 2011; 34: 453-61.

21 Lane RM, Farlow MR. Lipid homeostasis and apolipoprotein E in the development and progression of Alzheimer's disease. J Lipid Res 2005; 46: 949-68.

22 Wilson JD. The measurement of the exchangeable pools of cholesterol in the baboon. J Clin Invest 1970; 49: 655-65.

23 Dell RB, Mott GE, Jackson EM, Ramakrishnan R, Carey KD, McGill HC, et al. Whole body and tissue cholesterol turnover in the baboon. J Lipid Res 1985; 26: 327-37.

24 Prince PSM, Kannan NK. Protective effect of rutin on lipids, lipoproteins, lipid metabolizing enzymes and glycoproteins in streptozotocininduced diabetic rats. J Pharm Pharmacol 2006; 58: 1373-83.

25 Geethan PK, Prince PS. Antihyperlipidemic effect of D-pinitol on streptozotocin-induced diabetic wistar rats. J Biochem Mol Toxicol 2008; 22: 220-4.

26 Sarkar C, Cenedella R. Reactivity of key metabolic sterols in standard colorimetric assays for cholesterol. Lipids 1982; 17: 46-9.

27 Morris TG. A comparison of methods for the estimation of serum cholesterol and values in random samples of populations in the 5564 age group. J Clin Path 1959; 12: 518-23.

28 Uehara Y, Engel T, Li Z, Goepfert C, Rust S, Zhou X, et al. Polyunsaturated fatty acids and acetoacetate downregulate the expression of the ATP-binding cassette transporter A1. Diabetes 2002; 51: 2922-8.

29 Shen L, Tso P, Woods SC, Clegg DJ, Barber KL, Carey K, et al. Brain Apolipoprotein $E$ : an important regulator of food intake in rats. Diabetes 2008; 57: 2092-8.

30 Lenich CM, Chobanian AV, Brecher P, Zannis VI. Effect of dietary cholesterol and alloxan-diabetes on tissue cholesterol and apolipoprotein E mRNA levels in the rabbit. J Lipid Res 1991; 32: 431-8.
31 Suzuki R, Lee K, Jing E, Biddinger SB, McDonald JG, Montine TJ, et al. Diabetes and insulin in regulation of brain cholesterol metabolism. Cell Metab 2010; 12: 567-79.

32 Russell DW, Halford RW, Ramirez DMO, Shah R, Kotti T. Cholesterol 24-hydroxylase: An enzyme of cholesterol turnover in the brain. Annu Rev Biochem 2009; 78: 1017-40.

33 Kamboj SS, Chopra K, Sandhir R. Hyperglycemia-induced alterations in synaptosomal membrane fluidity and activity of membrane bound enzymes: beneficial effect of $\mathrm{N}$-acetylcysteine supplementation. Neuroscience 2009; 162: 349-58.

34 Nonomura K, Arai Y, Mitani H, Abe-Dohmae S, Yokoyama S. Insulin down-regulates specific activity of ATP-binding cassette transporter A1 for high density lipoprotein biogenesis through its specific phosphorylation. Atherosclerosis 2011; 216: 334-41.

35 Gerin I, Dolinsky VW, Shackman JG, Kennedy RT, Chiang S-H, Burant $\mathrm{CF}$, et al. LXRß is required for adipocyte growth, glucose homeostasis, and $\beta$ cell function. J Biol Chem 2005; 280: 23024-31.

36 Huang TH-W, Razmovski-Naumovski V, Salam NK, Duke RK, Tran VH, Duke CC, et al. A novel LXR- $\alpha$ activator identified from the natural product Gynostemma pentaphyllum. Biochem Pharmacol 2005; 70 : 1298-308.

37 Tamehiro N, Sato Y, Suzuki T, Hashimoto T, Asakawa Y, Yokoyama S, et al. Riccardin C: A natural product that functions as a liver $X$ receptor (LXR) $\alpha$ agonist and an LXR $\beta$ antagonist. FEBS Lett 2005; 579: 5299-304.

38 Shimano H, Yahagi N, Amemiya-Kudo M, Hasty AH, Osuga J, Tamura $\mathrm{Y}$, et al. Sterol regulatory element-binding protein-1 as a key transcription factor for nutritional induction of lipogenic enzyme genes. J Biol Chem 1999; 274: 35832-9.

39 Eberlé D, Hegarty B, Bossard P, Ferré P, Foufelle F. SREBP transcription factors: master regulators of lipid homeostasis. Biochimie 2004; 86: 839-48.

40 Shimomura I, Bashmakov Y, Ikemoto S, Horton JD, Brown MS, Goldstein JL. Insulin selectively increases SREBP-1c mRNA in the livers of rats with streptozotocin-induced diabetes. Proc Natl Acad Sci U S A 1999; 96: 13656-61.

41 Schiefelbein D, Goren I, Fisslthaler B, Schmidt H, Geisslinger G, Pfeilschifter J, et al. Biphasic regulation of HMG-CoA reductase expression and activity during wound healing and its functional role in the control of keratinocyte angiogenic and proliferative responses. J Biol Chem 2008; 283: 15479-90.

42 Easom RA, Zammit VA. Effects of diabetes on the expressed and total activities of 3-hydroxy-3-methylglutaryl-CoA reductase in rat liver in vivo. Reversal by insulin treatment. Biochem J 1985; 230: 747-52.

43 Ravid Z, Bendayan M, Delvin E, Sane AT, Elchebly M, Lafond J, et al. Modulation of intestinal cholesterol absorption by high glucose levels: impact on cholesterol transporters, regulatory enzymes, and transcription factors. Am J Physiol Gastrointest Liver Physiol 2008; 295: G873-85.

44 Proctor G, Jiang T, Iwahashi M, Wang Z, Li J, Levi M. Regulation of renal fatty acid and cholesterol metabolism, inflammation, and fibrosis in Akita and OVE26 mice with type 1 diabetes. Diabetes 2006; 55: 2502-9.

45 Zhao C, Dahlman-Wright K. Liver X receptor in cholesterol metabolism. J Endocrinol 2010; 204: 233-40.

46 Zager RA. Plasma membrane cholesterol: A critical determinant of cellular energetics and tubular resistance to attack. Kidney Int 2000; 58: 193-205.

47 Wang $\mathrm{H}$, Xie X, Zhang F, Zhou Q, Tao Q, Zou Y, et al. Evaluation of cholesterol depletion as a marker of nephrotoxicity in vitro for novel $\beta$-cyclodextrin derivatives. Food Chem Toxicol 2011; 49: 1387-93. 
48 Tsujikawa H, Song Y, Watanabe M, Masumiya H, Gupte SA, Ochi R, et al. Cholesterol depletion modulates basal L-type $\mathrm{Ca}^{2+}$ current and abolishes its $\beta$-adrenergic enhancement in ventricular myocytes. Am J Physiol Heart Circ Physiol 2008; 294: H285-92.

49 Sones WR, Davis AJ, Leblanc N, Greenwood IA. Cholesterol depletion alters amplitude and pharmacology of vascular calcium-activated chloride channels. Cardiovasc Res 2010; 87: 476-84.

50 Balut C, Steels P, Radu M, Ameloot M, Driessche WV, Jans D. Membrane cholesterol extraction decreases $\mathrm{Na}^{+}$transport in $\mathrm{A} 6$ renal epithelia. Am J Physiol Cell Physiol 2006; 290: C87-94.
51 Hao M, Head WS, Gunawardana SC, Hasty AH, Piston DW. Direct effect of cholesterol on insulin secretion. Diabetes 2007; 56: 232838.

52 Larsson S, Wierup N, Sundler F, Eliasson L, Holm C. Lack of cholesterol mobilization in islets of hormone-sensitive lipase deficient mice impairs insulin secretion. Biochem Biophys Res Commun 2008; 376: 558-62.

53 Hao M, Bogan JS. Cholesterol regulates glucose-stimulated insulin secretion through phosphatidylinositol 4,5-bisphosphate. J Biol Chem 2009; 284: 29489-98. 